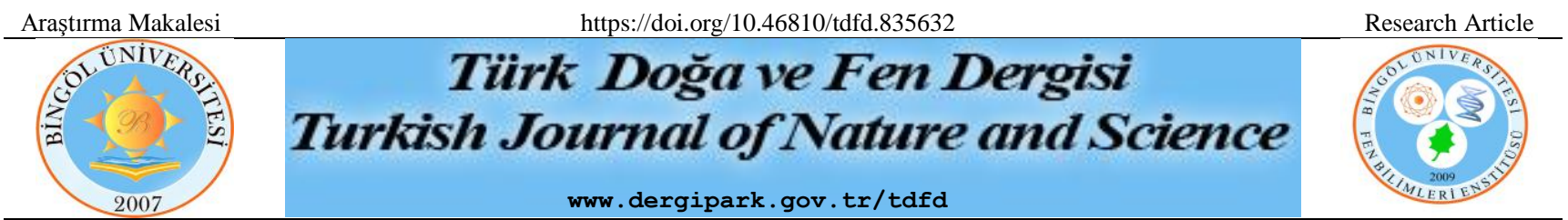

\title{
Characterization of a Thermally Stable $\beta$-galactosidase Produced by Thermophilic Anoxybacillus sp. AH1
}

\author{
Ömer ACER ${ }^{1 *}$, Fatma MATPAN BEKLER ${ }^{2}$ \\ ${ }^{1}$ *Siirt University, Medical Faculty, Department of Medical Microbiology, 56100, Siirt, Turkey \\ ${ }^{2}$ Dicle University, Science Faculty, Department of Molecular Biology and Genetics, 21280, Sur, Diyarbakır, Turkey
}

Ömer ACER ORCID No: 0000-0002-5314-0475

Fatma Matpan Bekler ORCID No: 0000-0001-8253-9568

*Corresponding author: Ömer ACER, oacer21@gmail.com, omer.acer@siirt.edu.tr

(Alınış: 03.12.2020, Kabul: 20.02.2021, Online Yayınlanma: 25.06.2021)

\begin{abstract}
Keywords Enzyme activity inhibition, Thermostable $\beta$-galactosidase, Enzyme purification, Anoxybacillus sp. AH1
\end{abstract}

\begin{abstract}
Thermostable $\beta$-galactosidases from thermophilic bacteria have attracted increasing interest to have various advantages in industrial and biotechnological applications. In this study, a highly thermally stable $\beta$-galactosidase produced by Anoxybacillus sp. AH1 was purified and characterized. The highest enzyme production was achieved after the bacterium was incubated for 24 hours. The enzyme was purified by precipitation with ammonium sulphate dialysis, gel filtration chromatography using Sephadex G-75. After the purification steps, $\beta$-galactosidase was found to be purified 10.2-fold and a yield of $13.9 \%$. The molecular mass of the $\beta$-galactosidase was estimated to be $75 \mathrm{kDa}$ by SDS-PAGE. The purified enzyme was highly stable and retained at $71 \%$ of the original activity at $60{ }^{\circ} \mathrm{C}$ and $53 \%$ at $70{ }^{\circ} \mathrm{C}$ within 120 minutes. The $\mathrm{Km}$ and $\operatorname{Vmax}$ values of purified $\beta$-galactosidase were calculated as $1.249 \mathrm{mM}$ and $0.5 \mu \mathrm{mol}$ minutes $^{-1}$, respectively. $\mathrm{Ca}^{2+}, \mathrm{Zn}^{2+}$, and $\mathrm{Mg}^{2+}$ significantly activated $\beta$-galactosidase activity, whereas enzyme activity was inhibited significantly by $\mathrm{Cu}^{+2}$ as well as by the metal ion chelators1,10phenanthroline (phen) and ethylenediaminetetraacetic acid (EDTA). The Purified $\beta$-galactosidase activity was increased by PMSF (phenylmethylsulfonyl fluoride), PCMB (pchloromercuribenzoic acid), DTT (dithiothreitol), and $\beta$-ME ( $\beta$-mercaptoethanol) at $2 \mathrm{mM}$, but inhibited completely by NEM (N-ethylmaleimide) at $1 \mathrm{mM}$.
\end{abstract}

\section{Thermofilik Anoxybacillus sp. AH1'den Üretilen Termostabil $\beta$-galaktosidazın Karakterizasyonu}

Anahtar
Kelimeler
Enzim aktivitesi
inhibisyonu,
Termostabil $\beta$ -
galaktosidaz,
Enzim
saflaştırma,
Anoxybacillus
sp. AH1

Öz: Termofilik bakterilerden elde edilen termostabil $\beta$-galaktosidazlar, endüstriyel ve biyoteknolojik uygulamalarda çeşitli avantajlara sahip oldukları için ilgi çekmektedir. Bu çalışmada, Anoxybacillus sp. AH1'den üretilen, oldukça termostabil olan $\beta$-galaktosidaz, saflaştırıldı ve karakterize edildi. En yüksek enzim üretimi, bakterinin 24 saat inkübe edilmesinden sonra elde edildi. Enzim, amonyum sülfat çöktürmesi, diyaliz ve jel filtrasyon kromatografisi (Sephadex G-75) kullanılırak saflaştırıldı. Saflaştırma aşamalarından sonra, $\beta$ galaktosidazın \% 13,9 verimle 10,2 kata kadar saflaştırıldığı tespit edildi. $\beta$-galaktosidazın moleküler kütlesi, SDS-PAGE ile $75 \mathrm{kDa}$ olarak tahmin edildi. Saflaştırılmış enzimin oldukça stabil olduğu ve 120 dakika sonunda $60^{\circ} \mathrm{C}$ 'de orijinal aktivitenin $\% 71$ 'ini, $70{ }^{\circ} \mathrm{C}$ 'de ise $\% 53$ 'ünü koruduğu tespit edildi. Saflaştırılmış $\beta$-galaktosidazın $K m$ ve Vmax değerleri sırasıyla 1,249 mM ve $0,5 \mu$ mol dakika ${ }^{-1}$ olarak hesapland. $\mathrm{Ca}^{2+,} \mathrm{Zn}^{2+}$ ve $\mathrm{Mg}^{2+} \beta$-galaktosidaz aktivitesini önemli ölçüde aktive ederken, $\mathrm{Cu}^{2+}$ ve metal iyon şelatörleri, 1,10-phenanthroline (phen) ve ethylenediaminetetraacetic acid (EDTA) enzim aktivitesini önemli ölçüde inhibe etmiştir. Saflaştırılmış $\beta$-galaktosidaz aktivitesi 2 mM PMSF (phenylmethylsulfonyl fluoride), PCMB (pchloromercuribenzoic acid), DTT (dithiothreitol), ve $\beta$-ME ( $\beta$-mercaptoethanol) ile artar iken, 1 mM NEM (N-ethylmaleimide) ile tamamen inhibe edildiği belirlendi. 


\section{INTRODUCTION}

$\beta$-Galactosidase (beta-D-galactohydrolase, EC3.2.1.23) is a hydrolase enzyme that hydrolyses the complex lactose into simple sugars, glucose, and galactose [1-2]. $\beta$-galactosidase is known as a commercially significant enzyme widely used especially in the food and pharmaceutical sectors [2-3]. The main biotechnological uses of $\beta$-galactosidase in the dairy industries are the production of galacto-oligosaccharides (GOSs) to use in probiotic foodstuffs and remove lactose from milk for lactose-intolerant people. GOSs are known as largely indigestible oligosaccharides and can support the growth of useful gut bacteria [4-5]. $\beta$-Galactosidase is largely used in the dairy industry to prevent crystallization of lactose in concentrated frozen dairy products such as condensed milk and ice cream, and also to solve the problem of whey disposal by converting whey into lactic acid. [6]. Besides, the hydrolysis of whey turns lactose into a very beneficial product, such as sweet syrup; this can be used in the various dairy, confectionery, bakery, and beverage industries. For this reason, lactose hydrolysis not only allows the non-lactose intolerant population to consume milk but also helps solve the environmental problem of whey destruction [1]. In addition, there are many studies on the use of whey in the production of many precious products. In this regard, thermostable $\beta$-galactosidases obtained from thermophilic bacteria have attracted increasing attention for use in such industrial processes [4].

Many studies on thermostable galactosidase which have been isolated from different microorganisms have been done so far, such as Alicyclobacillus acidocaldarius subsp. rittmannii [7], Bacillus stearothermophilus [8], Streptococcus thermophilus [9], Thermotoga naphthophila [10]. There are many studies on various enzymes from Anoxybacillus, for instance amylase [11], protease [12], glucose isomerase [13], carboxylesterase [14], esterase [15], and lipase [16]. However, to our knowledge, there have been a few studies so far on the characterization of thermostable $\beta$-galactosidase in Anoxybacillus species [1, 17-18].

In the present study, we aimed to purify and characterize a biotechnologically important thermally stable $\beta$ galactosidase from thermophilic Anoxybacillus sp. AH1.

\section{MATERIALS AND METHODS}

\subsection{Chemicals}

All chemicals used in this study were of analytical grade. Bovine serum albumin (BSA), Sephadex G-75, 3,5- pchlorobenzoic acid (PCMB), 1,10-phenanthroline (phen), dithiothreitol (DTT), iodoacetamide (IAA), Nethylmaleimide (NEM), sodium dodecyl sulphate (SDS), phenylmethanesulfonyl fluoride (PMSF) were purchased from Sigma (Sigma-Aldrich, St Louis, MO, USA). All culture media (Luria-Bertani medium), $\beta$ mercaptoethanol ( $\beta$-ME), and ethylenediaminetetraacetic acid (EDTA) were purchased from Merck (Germany).

\subsection{Bacterial strain, medium, and $\beta$-galactosidase} activity assay

In this study, thermophilic Anoxybacillus sp. AH1 isolated by Acer et al. [11] was used. To determine enzyme activity, Anoxybacillus sp. AH1 was grown on the solid Luria-Bertani medium (LB) containing 5bromo-4-chloro-3-indolyl- $\beta$-D-galactopyranoside (X$\mathrm{Gal}$ ) and then incubated at $65{ }^{\circ} \mathrm{C}$ for 2 days. After incubation of 48 hours, observed blue colonies transferred into LB liquid medium and incubated $60{ }^{\circ} \mathrm{C}$ for $48 \mathrm{~h}$ in a shaker. To follow bacterial growth, absorbance was measured at $600 \mathrm{~nm}$. The activity of $\beta$ galactosidase was detected by the release of $o$-NPG $(o-$ nitrophenyl- $\beta$-D-galactopyranoside, Sigma) according to Gül-Güven et al. [7].

\subsection{Investigation of the Effect of Incubation time on $\beta$-Galactosidase Production and Bacterial Growth}

I $\mathrm{mL}$ of fresh culture was transferred into $100 \mathrm{~mL}$ of the flasks containing $25 \mathrm{~mL}$ of $\mathrm{LB}$ and 3, 6, 9, 12, 24, 36, $42,48,60,72$ hours period the samples were taken to measure enzyme activity. In order to determine growth, the increase in absorbance at $600 \mathrm{~nm}$ was measured. The enzyme activity is measured by using a supernatant.

\section{4. $\beta$-Galactosidase Purification}

For $\beta$-galactosidase purification procedures, Anoxybacillus sp. AH1 cells were grown in $100 \mathrm{~mL}$ of LB medium at $60{ }^{\circ} \mathrm{C}$ for 24 hours. Then cells were centrifuged at $10.000 \mathrm{rpm}$ at $4{ }^{\circ} \mathrm{C}$ for 10 minutes. $0.1 \mathrm{M}$ Sodium phosphate buffer $\left(\mathrm{Na}_{2} \mathrm{HPO}_{4} / \mathrm{NaH}_{2} \mathrm{PO}_{4}\right)$ at $\mathrm{pH}$ 7.0 was used to re-suspend the pellet. For breaking cells, a Sonicator Ultrasonic Processor was used. After sonication, cells were centrifuged at $10.000 \mathrm{rpm}$ at $4{ }^{\circ} \mathrm{C}$ for 10 minutes. The supernatant represented the crude extract.

Ammonium sulphate to $70 \%$ saturation was used to precipitate the supernatant. Sodium phosphate buffer $(\mathrm{pH} 7.0,0.1 \mathrm{M})$ was used to dissolve the centrifuged precipitate and after which the sample was dialyzed overnight against the sodium phosphate buffer $(\mathrm{pH} 7.0$, $0.1 \mathrm{M}$ ). After the dialyzed, enzyme was concentrated by stirred ultrafiltration cell (PBGC membrane, Millipore), and applied to gel filtration chromatography using Sephadex G-75 $(1.5 \mathrm{~cm} \times 30 \mathrm{~cm})$, pre-equilibrated with the same buffer. To elute purified enzyme, sodium phosphate buffer $(0.1 \mathrm{M}, \mathrm{pH} 7.0)$ with the flow rate of 3 $\mathrm{mL}$ minutes ${ }^{-1}$ was used. Ultrafiltration was used for collecting the enzyme-containing fractions. All purification steps were fulfilled at $4{ }^{\circ} \mathrm{C}$. After each step was completed, enzyme activity was measured. Lowry method [19] was used to determine the protein content.

\subsection{Molecular Weight Estimation by Electrophoresis and Gel Filtration Chromatogram}

To estimate the molecular weight of the subunits, Sodium Dodecyl Sulphate Polyacrylamide Gel Electrophoresis (SDS-PAGE) using a vertical gel 
electrophoresis system was used. SDS-PAGE was carried out according to Laemmli [20]. Zymography (6bromo-2-naphthyl-galactopyranoside-BNG staining) analysis of the enzyme activity was carried out according to Gül-Güven et al. [7].

\subsection{Effect of $\mathrm{pH}$ and Temperature on the Purified Enzyme Activity}

To determent the optimum $\mathrm{pH}$ of the purified enzyme activity, the enzyme activity was studied at $\mathrm{pH}$ values ranging from 4.0 to 11.0 at $60{ }^{\circ} \mathrm{C}$. The $\mathrm{pH}$ stability of the purified enzyme was determined by incubating purified enzyme at $60{ }^{\circ} \mathrm{C}$ for 2 hours in different buffers (sodium citrate buffer ( $\mathrm{pH}$ 4.0-6.0); sodium phosphate buffer $(\mathrm{pH}$ 7.0-9.0); and glycine- $\mathrm{NaOH}$ buffer ( $\mathrm{pH} 11.0$ ).

The optimal temperature for enzyme activity was measured by incubating purified enzyme with $o$-NPG at different temperatures between 20 and $90{ }^{\circ} \mathrm{C}$ for 15 minutes at $\mathrm{pH}$ 8.0. The reactions were stopped with 500 $\mathrm{mL}$ of $1 \mathrm{M} \mathrm{Na}_{2} \mathrm{CO}_{3}$. The residual enzyme activity was measured after the purified enzyme incubated at 60 and $70{ }^{\circ} \mathrm{C}$ for $30,60,90$, and 120 minutes to determine the thermal stability of the enzyme. For the control, nonsubjected to heating enzyme activity was determined and considered as $100 \%$.

For determination of the optimum $\mathrm{pH}$ of the purified enzyme activity, the enzyme activity was studied at $\mathrm{pH}$ values ranging from 4.0 to 11.0 at $60{ }^{\circ} \mathrm{C}$. The $\mathrm{pH}$ stability of the purified enzyme was determined by incubating purified enzyme at $60{ }^{\circ} \mathrm{C}$ for 2 hours in different buffers (sodium citrate buffer ( $\mathrm{pH}$ 4.0-6.0); sodium phosphate buffer ( $\mathrm{pH}$ 7.0-9.0); and glycine$\mathrm{NaOH}$ buffer ( $\mathrm{pH} 11.0)$.

\subsection{Kinetic Properties of Purified Enzyme}

Lineweaver-Burk plot was used to calculate the $K m$ and Vmax values. The enzyme was assayed at various $o$-NPG substrate concentrations ranging from 0.5 to $15 \mathrm{mM}$ in $0.1 \mathrm{M}$ phosphate buffer at $\mathrm{pH} 8.0$ at $60{ }^{\circ} \mathrm{C}$ for 10 minutes.

\subsection{The Effects of Inhibitors}

The effects of various chemicals (IAA, $\beta$-ME, PMSF, PCMB, DTT, and NEM) and diff erent chelating agents (EDTA and phen), and metal ions $\left(\mathrm{Cu}^{2+} \mathrm{Zn}^{2+}, \mathrm{Ca}^{2+}\right.$, and $\left.\mathrm{Mg}^{2+}\right)$ on $\beta$ - galactosidase activity were determined by preincubating enzyme with all agents for 15 minutes. To calculate the remaining enzyme activity, the enzyme activity was determined under standard assay conditions. The activity was used as a control and taken as $100 \%$ in the absence of any additives. Chloride forms were used for all the metal. For dissolving divalent metals, chelating agents, chemicals, Tris-HCl buff er $(0.1 \mathrm{M}, \mathrm{pH}$ 7.0) was used, while ethanol used for dissolving PMSF and NEM, and methanol used for phen.

\section{RESULTS AND DISCUSSION}

\section{1. $\beta$-Galactosidase Production and Purification}

In this study, the time-dependent $\beta$-galactosidase production $(129.092 \mathrm{U} / \mathrm{mg})$ was maximum obtained at 24 hours (Fig. 1).

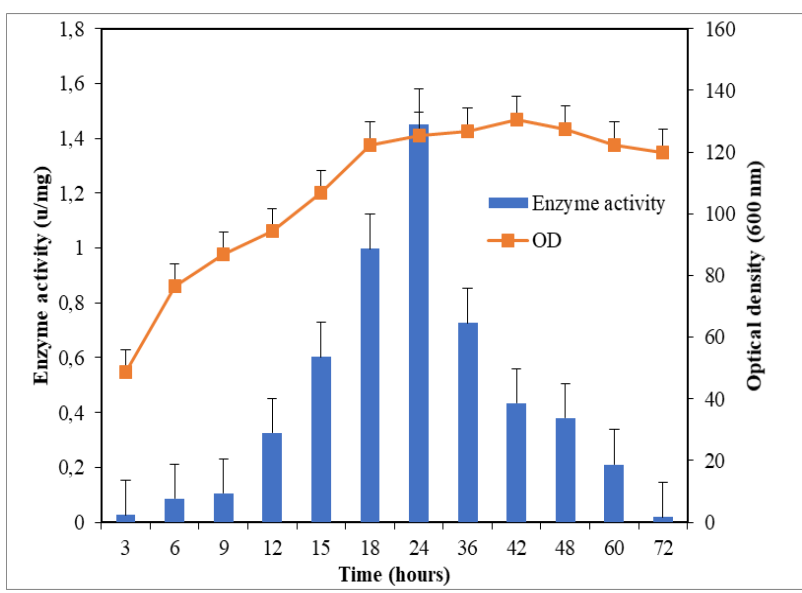

Figure 1. Time-dependent bacterial growth and enzyme activity

Table 1 shows the purification steps used for the purification of the enzyme. $\beta$-galactosidase was found to be purified up to 10.2 -fold with a $13.9 \%$ yield of the pure enzyme.

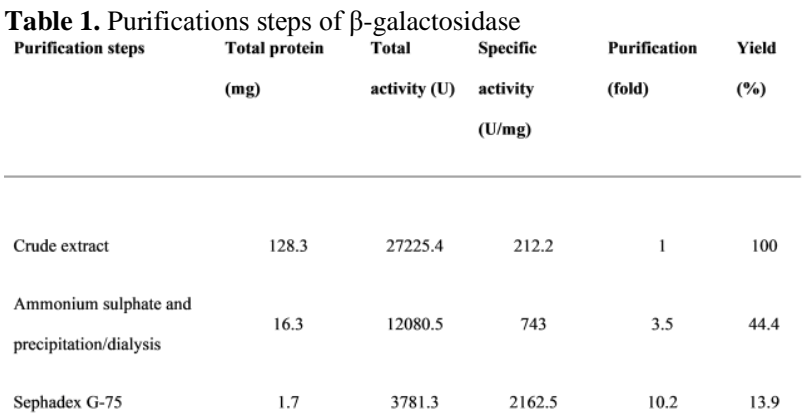

The partially purified enzyme was subjected to SDSPAGE analysis and BNG staining (Fig. 2a, b) to estimate the molecular weight of the enzyme and show $\beta$ galactosidase activity. According to data of the SDSPAGE (Figure 2a, lanes 2,3, and 4), the molecular weight of the purified enzyme was found as $75 \mathrm{kDa}$. In the previous studies, Osiriphun and Jaturapiree [21] also found the molecular weight of $\beta$-galactosidase purified from Anoxbacillus sp. B1.2 as $75 \mathrm{kDa}$. Besides, the molecular weight of $\beta$-galactosidase was reported as 68 $\mathrm{kDa}, 42 \mathrm{kDa}$, and $113 \mathrm{kDa}$ from Anoxybacillus sp. KP1 [17], Aspergillus terreus [22], and Bacillus velezensis [23]. The molecular weight of $\beta$-galactosidases belonging to Anoxybacillus was recorded by Uniport Protein sequence databases (http://www.uniprot.org/) in the range of $49.1-116.7 \mathrm{kDa}$. 


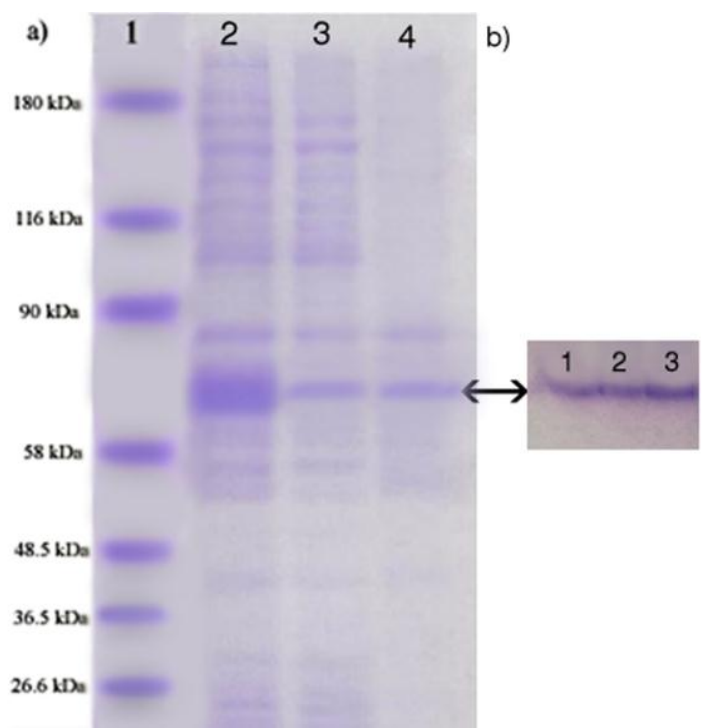

Figure 2. SDS-PAGE CBB-staining (a) BNG-staining (b) analysis of $\beta$-galactosidase from Anoxybacillus AH1. a: Lane 1, molecular mass markers [Sigma SDS7B2: a2- triosephosphate isomerase $(26.6 \mathrm{kDa})$, lactic dehydrogenase $(36.5 \mathrm{kDa})$, fumarase $(48.5 \mathrm{kDa})$, pyruvate kinase $(58 \mathrm{kDa})$, lactoferrin $(90 \mathrm{kDa}), \quad \beta$ - galactosidase $(116 \mathrm{kDa})$, macroglobulin (180 kDa)]; lanes $2 \mathrm{CBB}$-staining of partially purified $\beta$ - galactosidase (Sephadex G- 75), 3b: BNG-staining lane 1, crude extract; lane 2, ammonium sulphate precipitation and dialysis; lane 3, Sephadex G-75.

\subsection{Effect of Thermal, pH, and Kinetic Features on $\beta$-Galactosidase}

As shown in figure $3 \mathrm{a}$, purified $\beta$-galactosidase exhibits the highest activity at $\mathrm{pH} 8$ and the enzyme retained galactosidase activity of $60 \%, 80 \%, 69 \%$, and $58 \%$ at $\mathrm{pH}$ $7.0,9.0,10.0$, and 11.0, respectively. In the recent studies, maximum enzyme activity was reported at $\mathrm{pH}$ 7.0, 9.0, 7.2, 7.0 and 6.0 from Anoxybacillus falvithermus [1], Anoxybacillus ayderensis FMB1[18], Streptococcus thermophilus [9], Aspergillus terreus [22], and Klebsiella oxytoca ZJUH1705 [24], respectively. We also determined that purified $\beta$-galactosidase displayed $100 \%, 95 \%, 90 \%, 64 \%, 61 \%$ stability at $\mathrm{pH} 8.0,7.0,9.0$, 10.0 and 11.0 for 2 hours, respectively (Fig. 3b).

In the present study, the purified $\beta$-galactosidase exhibited maximum activity at $60{ }^{\circ} \mathrm{C}$ and displayed $87 \%$ of its peak activity at $70{ }^{\circ} \mathrm{C}$ (Fig. 4a). In recent studies, Matpan-Bekler et al. [17], Rani et al. [1] and Di Lauro et al. [25] reported optimum $\beta$-galactosidase activities from Anoxybacillus sp. KP1, A. flavithermus, and Alicyclobacillus acidocaldarius at $60{ }^{\circ} \mathrm{C}$, respectively. On the other hand, Murphy et al. [26] reported optimum $\beta$-galactosidase activity from Alicyclobacillus vulcanalis as $70{ }^{\circ} \mathrm{C}$. As seen in Figure $4 \mathrm{~b}$, the purified $\beta$ galactosidase was highly stable up to 2 hours. It was found that the purified enzyme retained $71 \%$ of the original activity at $60{ }^{\circ} \mathrm{C}$ and $53 \%$ at $70{ }^{\circ} \mathrm{C}$. The tolerance of thermostable $\beta$-galactosidases to pasteurization and immobilization is known to have an economic advantage [27] and is of great interest for possible use in the industrial processing of lactosecontaining fluids [7].
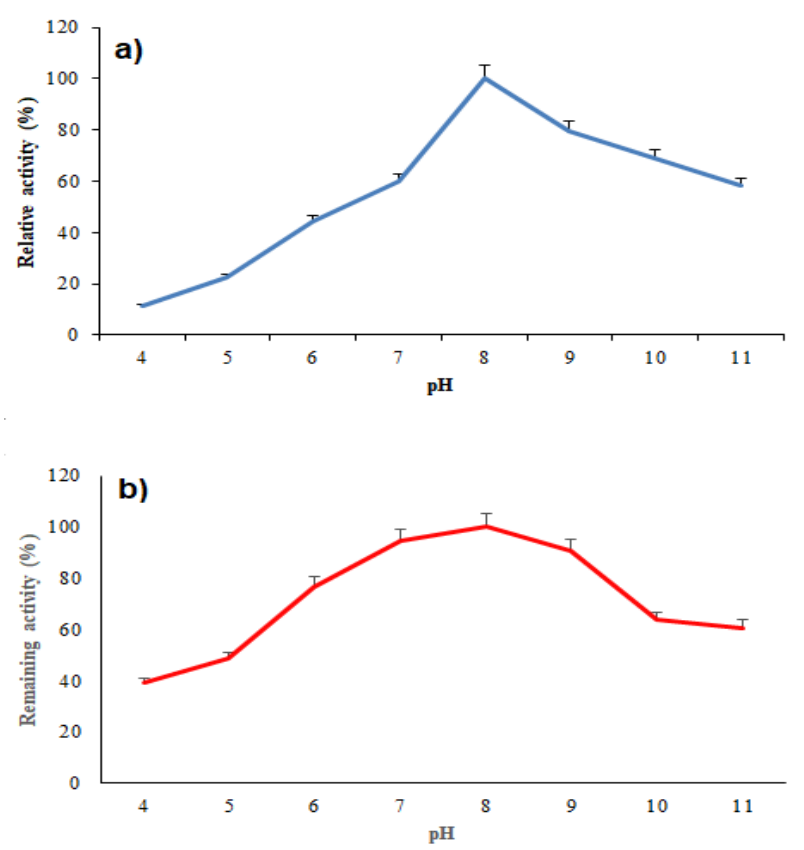

Figure 3. Effect of a) $\mathrm{pH}$ on the $\beta$-galactosidase activity b) $\mathrm{pH}$ on the stability of $\beta$-galactosidase activity
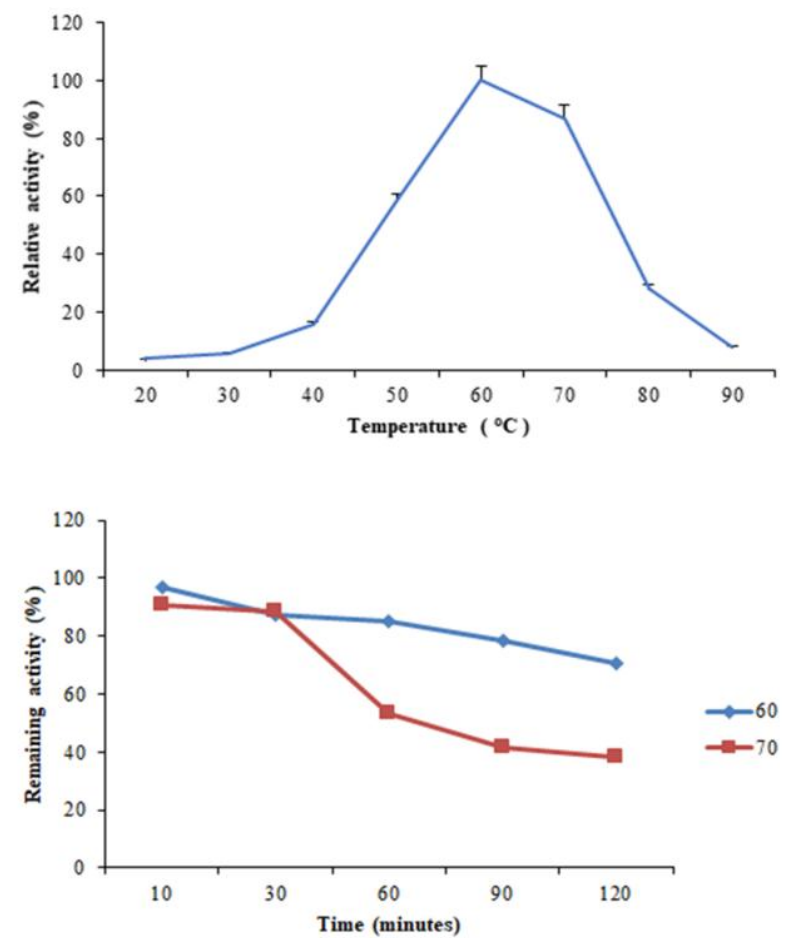

Figure 4. Eff ect of: a) temperature on the Anoxybacillus sp. AH1 $\beta$ galactosidase activity. b) temperature on the stability of Anoxybacillus sp. AH1 $\beta$-galactosidase activity.

To perform Kinetic studies of the purified enzyme, various concentrations of $o$-NPG were used as substrate. As shown in Figure 5, Km and Vmax values were calculated as $1,249 \mathrm{mM}$ and $0.5 \mu \mathrm{mol}$ minutes $^{-1}$, respectively, using the Lineweaver-Burk plot. 


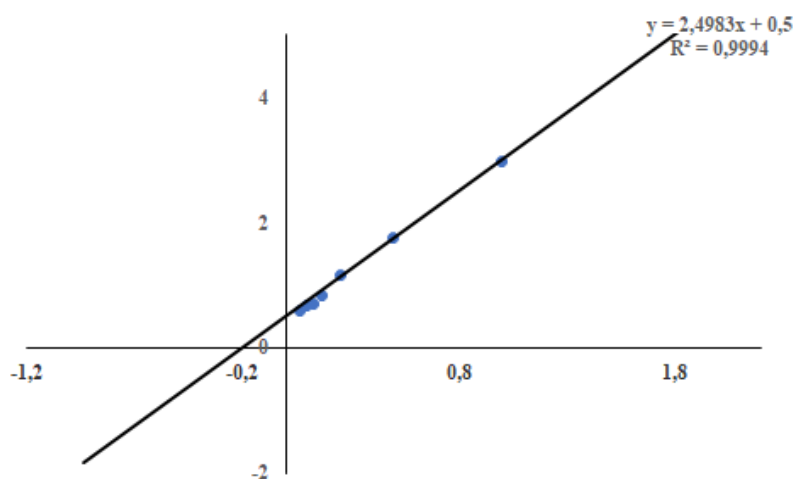

Figure 5. Lineweaver-Burk plot for $K m$ and $V \max$ values of the $\beta$ galactosidase in the presence of diff erent concentrations of $o-\mathrm{NPG}$

The affinity of the enzyme to its substrate is reflected by $K m$. The worth of $K m$ is comparatively smaller, displaying a higher enzyme affinity for its substrate. As substrate concentrations become very high, Vmax is the limiting velocity. Vmax is expressed in product units that are generated per unit of time. High affinity is expressed by low $\mathrm{Km}$ value. The enzyme's $\mathrm{Km}$ values range is in a wide range especially for most enzymes of industrial significance. Due to the high catalytic efficiency and specificity of the enzyme, $o$ NPG is by far the best substrate to determine the activity of $\beta$ galactosidase. In the studies published recently, $\mathrm{Km}$ and Vmax values for $o$ NPG substrate were reported as 1.3 $\mathrm{mM}$ and $3.23 \mathrm{U} / \mathrm{mg} / \mathrm{min}$ for A. flavithermus PW10 [23], $0,48 \mathrm{mM}$, and 0.96 for A. terreus (KUBCF1306) [22], $5.62 \mathrm{mM}$ and $167.1 \mu \mathrm{mol} \mathrm{mg}^{-1}$ for $K$. oxytoca ZJUH1705 [24].

\subsection{Investigation of the Effect of Various Chemicals Reagents and Metal Ions on the Purified $\beta$ - Galactosidase}

Understanding the interaction between enzymes and metal ions is important for enzyme activity because proteins are known as essential biological molecules that are required for the appropriate functioning of cells and organisms. As shown in Table 2, purified $\beta$ galactosidase activity was enhanced significantly by $\mathrm{Ca}^{2+}(60 \%$ at $10 \mathrm{mM}), \mathrm{Mg}^{2+}(77 \%$ at $20 \mathrm{mM})$ and $\mathrm{Zn}^{2+}$ $(43 \%$ at $10 \mathrm{mM})$ whereas $\mathrm{Cu}^{2+}(100 \%$ at $1 \mathrm{mM})$ and metal ion chelators, phen $(100 \%)$ and EDTA $(70 \%)$ at 10 $\mathrm{mM}$, significantly inhibited enzyme activity. $\beta$ galactosidase inhibition in the presence of metal ions present in milk and dairy products is an important aspect. According to the data obtained from our study, we can suggest that $\beta$-galactosidase of Anoxybacillus sp. AH1 is a metal-dependent enzyme.

In the previous studies, Rani et al. [1] also reported that $\beta$-galactosidase of $A$. flavithermus activity was enhanced in the presence of $\mathrm{Ca}^{2+}, \mathrm{Mg}^{2+}$ and $\mathrm{Zn}^{2+}$ while decreased in the presence of EDTA. Matpan Bekler et al. [17] reported that $\mathrm{Ca}^{2+}$ and $\mathrm{Mg}^{2+}$ enhanced the $\beta$ galactosidase activity of Anoxybacillus sp. KP1, whereas $\mathrm{Cu}^{2+}$ inhibited $\beta$-galactosidase activity as well. Calcium is well known as an important component of milk. For this reason, evaluation of $\beta$-galactosidase stability is necessary with different amounts of $\mathrm{CaCl}_{2}$ (calcium chloride) [4]. As shown in Table 2, the activity of $\beta$ galactosidase was enhanced significantly in the presence of $\mathrm{Ca}^{2+}$. In most $\beta$-galactosidases, $\mathrm{Mg}^{2+}$ is known to be required for enzyme activity as well. In recent studies, Ustok et al. [28], Matpan Bekler et al. [17], and Rani et al. [1] reported that $\mathrm{Mg}^{2+}$ increased $\beta$-galactosidase activity as well.

As can be seen in Table 2, DTT and $\beta$-ME reagents containing SH groups increased the purifiedgalactosidase activity by 122 and $18 \%$, respectively, at 2 mM. Nevertheless, NEM completely inhibited the enzyme activity at $1 \mathrm{mM}$. We can conclude that there is at least one essential cysteine residue that is modified by chemicals in the active site of the enzyme due to inhibition by NEM. On the other hand, it is interesting to note that the IAA (Iodoacetamide) which is an alkylating reagent through $\mathrm{SH}$ group had little effect on the enzyme. Enzyme activity was also enhanced by PMSF for $70 \%$ at $8 \mathrm{mM}$. In recent studies, Gül-Güven et al. (2011) also reported reagents containing SH groups such as 2-mercaptoethanol and DTT enhanced $\beta$-galactosidase activity in Alicyclobacillus acidocaldarius subsp. rittmannii. Actually, to our knowledge, there are not many studies on the inhibition of $\beta$-galactosidase purified from the species Anoxybacillus genus. Therefore, this study may be a guide for future studies.

Table 2 Effect of metal ion chelators, divalent metal ions, and chemicals on the activity of purified $\beta$-galactosidase

\begin{tabular}{|c|l|l|l|l|l|l|l|l|l|}
\hline $\begin{array}{l}\text { Divalent } \\
\text { metals, ion } \\
\text { chelators, and } \\
\text { chemicals }\end{array}$ & \multicolumn{7}{|c|}{ c m. $^{-1}$} \\
\hline & $0.2 \mathrm{mM}$ & $0.4 \mathrm{mM}$ & $1 \mathrm{mM}$ & $2 \mathrm{mM}$ & $4 \mathrm{mM}$ & $5 \mathrm{mM}$ & $8 \mathrm{mM}$ & $10 \mathrm{mM}$ & $20 \mathrm{mM}$ \\
\hline & NT & NT & 117 & 123 & NT & 127 & NT & 160 & 239 \\
\hline $\mathrm{Ca}^{2+}$ & Percentage activity retained (\%) \\
\hline $\mathrm{Mg}^{2+}$ & NT & NT & 108 & 144 & NT & 148 & NT & 177 & 211 \\
\hline $\mathrm{Cu}^{2+}$ & NT & NT & 0 & 0 & NT & 0 & NT & 0 & 0 \\
\hline $\mathrm{Zn}^{2+}$ & NT & NT & 102 & 116 & NT & 120 & NT & 143 & 222 \\
\hline EDTA & NT & NT & 62 & 58 & 53 & NT & 43 & 30 & NT \\
\hline PHE & NT & NT & NT & 27 & NT & NT & 0 & 0 & NT \\
\hline DTT & NT & NT & 194 & 222 & 233 & NT & 208 & 180 & NT \\
\hline P-ME & NT & NT & 129 & 118 & 75 & NT & 92 & 8 & NT \\
\hline PMSF & NT & NT & 99 & 160 & 165 & NT & 170 & 117 & NT \\
\hline PCMB & 283 & 263 & 203 & 217 & NT & NT & NT & NT & NT \\
\hline NEM & NT & NT & 0 & 0 & 0 & NT & 0 & 0 & NT \\
\hline LAA & NT & NT & 113 & 111 & 91 & NT & 106 & 67 & NT \\
\hline
\end{tabular}

$\mathrm{NT}=$ not tested, $0=$ activity not determined.

\section{CONCLUSION}

In the present study, we found that metal ions such as magnesium and calcium increased the activity of the purified $\beta$-galactosidase. Calcium is well known as an important component of milk. For this reason, In the presence of different amounts of $\mathrm{CaCl}_{2}$, the stability of $\beta$-galactosidase is needed to be evaluated. $\mathrm{Mg}^{2+}$ is known to be required for enzyme activity in most $\beta$ galactosidases as well. We evaluated the effect of various inhibitors and chemicals on the $\beta$-galactosidase activity, which may further clarify the nature of the purified enzyme. This $\beta$-galactosidase from Anoxybacillus sp. AH1 was found to be highly 
temperature resistant and maintains high relative activity levels at temperatures up to $70^{\circ} \mathrm{C}$. This property would allow this enzyme to be used for various industrial processes at high temperatures that require a thermoactive $\beta$-galactosidase, such as in the manufacture of synthetic disaccharide lactulose, or the manufacture of milk and milk products free of lactose. To our knowledge, there are not many studies on the inhibition of $\beta$-galactosidase purified from the species of Anoxybacillus genus. Therefore, this study may be a guide for future studies.

\section{Acknowledgment}

The authors thank to Dicle University, Science Faculty, Department of Biology and Professor Dr. Kemal GÜVEN for supporting this study.

\section{REFERENCES}

[1] Rani V, Sharma P, Dev K. Characterization of thermally stable $\beta$-galactosidase from Anoxybacillus flavithermus and Bacillus licheniformis isolated from Tattapani Hotspring of North-Western Himalayas, India. Int. J. Curr. Microbiol. 2019; 8 (1): 2517-2542.Carlson BM. Human embryology and developmental biology. 4th ed. St. Louis: Mosby; 2009.

[2] Banerjee G, Ray A, Das SK, Kumar R, Ray AK. Chemical extraction and optimization of intracellular $\beta$-galactosidase production from the bacterium Arthrobacter oxydans using BoxBehnken design of response surface methodology. Acta Alimentaria. 2016;45 (1):93-103.

[3] Natarajan J, Christobell C, Kumar DM, Balakumaran MD, Kumar MR, Kalaichelvan, PT. Isolation and characterization of $\beta$-galactosidase Producing Bacillus sp. from dairy effluent. World Appl. Sci. J. 2012;17 (11):1466-1474.

[4] Gül-Güven R, Kaplan A, Guven K, Matpan-Bekler F, Dogru M. Effects of various inhibitors on $\beta$ galactosidase purified from the thermoacidophilic Alicyclobacillus acidocaldarius subsp. rittmannii isolated from Antarctica. Biotechnol. Bioprocess Eng. 2011;16 (1):114-119.

[5] Liu Z, Zhao C, Deng Y, Huang Y, Liu B, 2015. Characterization of a thermostable recombinant $\beta$ galactosidase from a thermophilic anaerobic bacterial consortium YTY-70. Biotechnol. Biotechnol. Equip. 2015;29 (3):547-554.

[6] Chanalia P, Gandhi D, Attri P, Dhanda S. Purification and characterization of $\beta$-galactosidase from probiotic Pediococcus acidilactici and its use in milk lactose hydrolysis and galactooligosaccharide synthesis. Bioorg. Chem.2018; 77:176-189.

[7] Gul-Guven R, Guven K, Poli A, Nicolaus B. Purification and some properties of a $\beta$ galactosidase from the thermoacidophilic Alicyclobacillus acidocaldarius subsp. rittmannii isolated from Antarctica. Enzyme Microb. Technol. 2007; 40 (6): 1570-1577.
[8] Chen W, Chen H, Xia Y, Yang J, Zhao J, Tian F, et al. Immobilization of recombinant thermostable $\beta$ galactosidase from Bacillus stearothermophilus for lactose hydrolysis in milk. J. Dairy Sci. 2009; 92 (2): 491-498

[9] Princely S, Basha NS, Kirubakaran JJ, Dhanaraju, MD. Biochemical characterization, partial purification, and production of an intracellular betagalactosidase from Streptococcus thermophilus grown in whey. Eur. J. Exp. Biol. 2013; 3 (2): 242 251.

[10] Kong F, Wang Y, Cao S, Gao R, Xie G Cloning, purification and characterization of a thermostable $\beta$-galactosidase from Thermotoga naphthophila RUK-10. Process Bioche. 204; 49 (5): 775-82.

[11] Acer Ö, Pirinççioğlu H, Bekler FM, Gül-Güven R, Güven K. 2015. Anoxybacillus sp. AH1, an $\alpha$ amylase-producing thermophilic bacterium isolated from Dargeçit Hot Spring. Biologia. 2015; 70 (7): 853-862.

[12] Matpan-Bekler F, Acer Ö, Güven, K. Production and purification of novel thermostable alkaline protease from Anoxybacillus sp. KP1. Cell. Mol. Biol. 2015; 61 (4): 113-120.

[13] Karaoglu H, Yanmis D, Sal FA, Celik A, Canakci S, Belduz AO. 2013. Biochemical characterization of a novel glucose isomerase from Anoxybacillus gonensis G2T displays a high level of activity and thermal stability. J. Mol. Catal. 2013;97: 215-24.

[14] Ay F, Karaoglu H, Inan K, Canakci S, Belduz AO, 2011. Cloning, purification, and characterization of a thermostable carboxy- lesterase from Anoxybacillus sp. PDF1. Protein Expr. Purif. 2011;80 (1): 74-9.

[15] Chiş L, Hriscu M, Bica A, Toşa M, Nagy G, Róna $\mathrm{G}$, et al. 2013. Molecular cloning and characterization of a thermostable esterase/lipase produced by a novel Anoxybacillus flavithermus strain. J. Gen. Appl. Microbiol. 2013;59 (2): 119134.

[16] Bakir ZB, Metin K. Purification and characterization of an alkali-thermostable lipase from thermophilic Anoxybacillus flavithermus HBB 134. J Microbiol Biotechnol, 2016;26 (6): 1087-97.

[17] Matpan Bekler F, Yalaz S, Acer O, Guven K. Purification of thermostable $\beta$-galactosidase from Anoxybacillus sp. KP1 and estimation of the combined effect of some chemicals on enzyme activity using semiparametric errors in variables model. Fresenius Environ Bull. 2017;26: 22512259.

[18] Matpan-Bekler F, Yalaz S, Güven RG, Acer O, Güven K 2018. Characterization of thermostable $\beta$ galactosidase from Anoxybacillus ayderensis and optimal design for enzyme inhibition using semiparametric EIV models. TOJSAT. 2018;8 (2): 32-37.

[19] Lowry OH, Rosebrough NJ, Farr AL. Protein measurement with the folin phenol reagent. The Journal of Biological Chemistry. 1951;193 (1): $265-275$. 
[20] Laemmli U. Cleavage of structural proteins during the assembly of the head of Bacteriphage T4. Nature. 1970;277: 680-685.

[21] Osiriphun S, Jaturapiree P. Isolation and Characterization of $\beta$-galactosidase from the Thermophile B1.2. AJOFAI. 2009;04: 135-143.

[22] Vidya B, Palaniswamy M, Angayarkanni J, Nawaz KA, Thandeeswaran M, Chaithanya, KK, et al. Purification and characterization of $\beta$-galactosidase from newly isolated Aspergillus terreus (KUBCF1306) and evaluating its efficacy on breast cancer cell line (MCF-7). Bioorg. Chem. 2020; 94:103442.

[23] Liu Y, Wu Z, Zeng X, Weng P, Zhang X., Wang, C. A novel cold-adapted phospho-betagalactosidase from Bacillus velezensis and its potential application for lactose hydrolysis in milk. Int. J. Biol. Macromol. 2021;166: 760-770.

[24] Huang J, Zhu S, Zhao L, Chen L, Du M, Zhang C, et al. A novel $\beta$ - galactosidase from Klebsiella oxytoca ZJUH1705 for efficient production of galacto-oligosaccharides from lactose. Appl. Microbiol. Biotechnol. 2020;104: 6161-6172.

[25] Di Lauro B, Strazzulli A, Perugino G, Cara FL, Bedini E, Corsaro MM, et al. Isolation and characterization of a new family $42 \beta$-galactosidase from the thermoacidophilic bacterium Alicyclobacillus acidocaldarius: Identification of the active site residues. Biochim Biophys Acta Proteins Proteom. 2008;1784 (2): 292-301.

[26] Murphy J, Ryan MP, Walsh G. Purification and characterization of a novel $\beta$ galactosidase from the thermoacidophile Alicyclobacillus vulcanalis. Appl. Biochem. Biotechnol. 2020;191(3):1190-1206.

[27] Ohtsu N, Motoshima H, Goto K, Tsukasaki F, Matsuzawa $H$. Thermostable $\beta$-galactosidase from an extreme thermophile, Thermus sp. A4: Enzyme purification and characterization, and gene cloning and sequencing. Biosci. Biotechnol. Biochem. 1998;62 (8): 1539-45.

[28] Ustok FI, Tari C, Harsa S. Biochemical and thermal properties of $\beta$-galactosidase enzymes produced by artisanal yoghurt cultures. Food Chem. 2010; 119 (3): 1114-20. 